\title{
MAP2 wt Allele
}

National Cancer Institute

\section{Source}

National Cancer Institute. MAP2 wt Allele. NCI Thesaurus. Code C125215.

Human MAP2 wild-type allele is located within 2q34-q35 and is approximately $310 \mathrm{~kb}$ in length. This allele, which encodes microtubule-associated protein 2 , may be involved in the stabilization of microtubules. 